\title{
The Standardized Mortality Ratio due to Man Made Disaster in Ethiopia
}

\author{
Kaleab Tesfaye Tegegne ${ }^{1 *}$, Abiyu Ayalew Assefa ${ }^{1}$, Medhin Geta ${ }^{1}$, Andualem Zenebe ${ }^{1}$, Wosenyeleh \\ Semeon Bagajjo ${ }^{2}$, Musie Rike ${ }^{3}$ and Belayneh Feleke Weldeyes ${ }^{4}$ \\ ${ }^{1}$ Department of Public Health, Hawassa College of Health Science, Hawassa, Ethiopia \\ ${ }^{2}$ Dean of Hawassa College of Health Science, Hawassa, Ethiopia \\ ${ }^{3}$ Research and Publication Directorate, Hawassa College of Health Science, Hawassa, Ethiopia \\ ${ }^{4}$ Department of Mid Wifery, Hawassa College of Health Science, Hawassa, Ethiopia \\ *Corresponding author: Kaleab Tesfaye Tegegne, Department of Public Health, Hawassa College of Health Science, Hawassa, \\ Ethiopia
}

\begin{tabular}{lll}
\hline ARTICLE INFO & & ABSTRACT \\
\cline { 1 - 1 } $\begin{array}{l}\text { Received: 蔧 November 09, } 2021 \\
\text { Published: }\end{array}$ & $\begin{array}{l}\text { Citation: Kaleab Tesfaye Tegegne, Abiyu Ayalew Assefa, Medhin Geta, Andualem Zenebe, } \\
\text { Wosenyeleh Semeon Bagajo, et al., The Standardized Mortality Ratio due to Man Made } \\
\text { Disaster in Ethiopia. Biomed J Sci \& Tech Res 40(1)-2021. BJSTR. MS.ID.006407. }\end{array}$ \\
\hline
\end{tabular}

\section{Introduction}

\section{Man-Made Disaster}

Man-made disasters have an element of human intent involving a failure of a man-made system, as opposed to natural disasters resulting from natural hazards. Man-made disasters include crime, arson, civil disorder, terrorism, war, biological/chemical threat, cyber-attacks, etc. From the above listed manmade disasters, Terrorism is the recent and a major cause of human loses in Ethiopia. The Tigray People Liberation Front Terrorists group is a cause for a significant number of deaths of civilians in many areas of Ethiopia among these Mai kadara, Galicoma, Chena, Kobo, Wuchale, Meresa, Gayenete, Deberezebete and Kombolcha are the major places where many death of civilians occurred by Tigray People Liberation Front Terrorists group.

\section{Terrorism}

Terrorism is the use of force or violence against persons or property in violation of the criminal laws of the United States for purposes of intimidation, coercion, or ransom. Terrorists often use threats to create fear among the public to try to convince citizens that their government is powerless to prevent terrorism and to get immediate publicity for their causes [1].

In Ethiopia, from October 2020 up to now (November 2021 Man Made Disaster occurred particularly by Tigray People Liberation Front Terrorists group in many parts of the country especially in Amhara and Afar Regions of Ethiopia. They cause a large number of death, displacement, violence, material and resource damage in Amhara and Afar Regions of Ethiopia . In this short communication, we are interested to disseminate the extent of death due to Tigray People Liberation Front Terrorists group in two places, Mai kadara, Amhara region and Galicoma, Afar region by calculating Standardized Mortality Ratio (SMR) and this will help the international community to understand the situation in our country Ethiopia. The Standardized Mortality Ratio (SMR) is a measure of mortality in a study population, relative to mortality in a reference population. The SMR indicates the relative excess or decrement in the actual mortality experience in the study 
population with respect to what might have been expect had it experienced the force of mortality in the standard (or reference) population [2].

We calculate the SMR in two places of Ethiopia

1. Mai kadara, Amhara region

2. Galicome, Afar region

The number of observed death due to manmade disaster (killing by TPLF Terrorist group). In Mai kadara, Amhara Region is 600 whereas 242 observed deaths in Galicoma, Afar Region. The total estimated population of Mai kadara is 45,000 and Galicoma is 36,816 [3-5]. We use Ethiopia population as standard population in order to compare deaths rate due to Manmade disaster (killing by TPLF Terrorist group based on ethnicity) of this two place to standard population (Ethiopia, crude death rate).

We calculate expected deaths by multiplying study population with crude death rate (standard rate) of Ethiopia in 2020 which is 6.3 per 1,000. Expected death in Mai kadara is $45,000 \times 6.3 / 1000=283.5$ Expected death in Galicoma is $36,813 \times 6.3 / 1000=231.92$. Standard mortality ratio $=$ observed death $/$ expected death $\times 100$. Standard mortality ratio for Mai kadara is $212 \%$. 600/283.5 $=2.12=212 \%$. In Mai kadara ,Amhara Region , 112\% more deaths occurred than would have been expected. Standard mortality ratio for Galicoma

\section{ISSN: 2574-1241}

DOI: 10.26717/BJSTR.2021.40.006407

Kaleab Tesfaye Tegegne. Biomed J Sci \& Tech Res

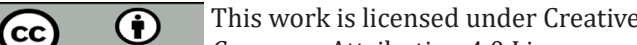
Commons Attribution 4.0 License

Submission Link: https://biomedres.us/submit-manuscript.php
242/231.92=1.043=104.3\%. In Galicoma ,Afar region 4\% more deaths occurred than would have been expected. We have calculated the expected death from the total study population and not using the usual formula that is adding the expected death from each age group in the study population because we did not find the population size in each age group of the study population. The standard mortality ratio is a hypothetical rate and our finding is approximate that is we have used high expected death so our standard mortality ratio is lower than it would be calculated by adding expected deaths from each age group in the study population. Our finding shows there is a significant number of deaths of civilians due to Manmade disaster (killing by TPLF Terrorist group based on ethnicity) in these two places Mai kadara, Amhara region and Galicoma ,Afar region of Ethiopia.

\section{References}

1. Man-Made Disaster. Monroe County, FL.

2. Victor J Schoenbach (2000) Understanding the Fundamentals of Epidemiology an evolving text University of North Carolina School of Public Health Chapel Hill.

3. (2020) Rapid Investigation into Grave Human Rights Violations in Maikadra: Preliminary Findings (Digital report). Addis Ababa: Ethiopian Human Rights Commission.

4. (2020) Maikadra Preliminary Findings English Final.

5. Al Jazeera (2021) Ethiopia calls on civilians to join army to fight Tigray forces.

$\begin{array}{ll}\text { BIOMEDICAL } & \text { Assets of Publishing with us } \\ \text { RESEARCHES } & \text { - Global archiving of articles } \\ \text { - Immediate, unrestricted online access } & \text { - Rigorous Peer Review Process } \\ & \text { - Authors Retain Copyrights } \\ \end{array}$

